\title{
PELATIHAN MANAJEMEN ORGANISASI KEPEMUDAAN DALAM UPAYA PENGUATAN IDEALISME KEPEMUDAAN GUNA MENANGKAL PAHAM RADIKALISME
}

\author{
BAHRUR ROSYID \\ Dosen Prodi. Ekonomi Syariah, FEBI UIN Mataram
}

\begin{abstract}
Abstrak: Dalam kaidah bahasa Qurani pemuda atau yang disebut "asysyabab"didefinisikan dalam ungkapan sifat dan sikap seperti: 1). berani merombak dan bertindak revolusioner terhadap tatanan sistem yang rusak, 2). memiliki standar moralitas (iman), berwawasan, bersatu, optimis dan teguh dalam pendirian serta konsisten dalam dengan perkataan, seperti tergambar pada kisah Ash-habul Kahfi (para pemuda penghuni gua. 3). seorang yang tidak berputus-asa, pantang mundur sebelum cita-citanya tercapai. Peran penting dari seorang pemuda adalah pada kemampuannya melakukan perubahan. Perubahan menjadi indikator suatu keberhasilan terhadap sebuah gerakan pemuda. Perubahan menjadi sebuah kata yang memiliki daya magis yang sangat kuat, sehingga membuat gentar orang yang mendengarnya, terutama mereka yang telah merasakan kenikmatan dalam iklim status quo.

Tujuan pengabdian pada masyarakat dengan pengambilan tema dalam kegiatan ini adalah Untuk melatih Pemuda dalam meningkatkan Idealismenya guna menangkal Paham Radikalisme dalam sebuah Wadah Organisasi Kepemudaan, untuk Membentuk Wadah Organisasi Kepemudaan dalam hal ini adalah Karang Taruna, sebagai lembaga penghimpun dan menyalurkan bakat dan minat masing-masing pemuda, harapannya supaya pemuda di Lingkungan Gegutu Timur terarah dan tepat menyalurkan minat dan bakatnya, sehingga akan terbentuk idealisme pemudanya secara kuat dan kokoh guna menangkal paham Radikalisme. Kegiatan pemberdayaan masyarakat ini diharapkan dapat memberikan manfaat di antaranya : Peningkatan pemahaman dan kesadaran Pemuda tentang pemberdayaan diri dengan potensi yang ada melalui Wadah Organisasi Kepemudaan, Dengan adanya Wadah Organisasi Kepemudaan ini dapat menjadi wadah menyalurkan potensi, minat dan bakat berikut mengolalanya tentunya dengan proses pendampingan secara kontinue dan dievaluasi pada ahir kegiatan, sehingga kedepannya akan tercipta rasa aman dan tentram dalam kehidupan bermasyarakat, dengan Pemuda yang punya Inisiatif tinggi untuk melaksankan perubahan, tentunya perubahan ini didasari dengan jiwa kreatif dan inovatif, maka akan terjawab bahwa pemuda merupakan tulang punggung kemajuan dalam kehidupan bermasyarakat, berbangsa dan bernegara.
\end{abstract}

Kata Kunci : Kepemudaan

\section{PENDAHULUAN}

Berbagai definisi berkibar akan makna kata Pemuda, baik ditinjau dari fisik maupun phisikis akan siapa yang pantas disebut pemuda serta pertanyaan apakah pemuda itu identik dengan semangat atau usia. Terlebih kaitannya dengan makna hari Sumpah Pemuda. Princeton mendefinisikan kata pemuda (youth) dalam kamus Webstersnya sebagai "the time of life between childhood 
Transformasi, Vol. 13, No. 2, Juli 2017:147 - 163

and maturity; early maturity; the state of being young or immature or inexperienced; the freshness and vitality characteristic of a young person", sedangkan dalam kerangka usia, WHO menggolongkan usia 10 - 24 tahun sebagai young people, sedangkan remaja atau adolescence dalam golongan usia 10 -19 tahun. Contoh lain di Canada dimana negara tersebut menerapkan bahwa "after age 24, youth are no longer eligible for adolescent social services".

Definisi yang berbeda ditunjukkan oleh Al-Quran. Dalam kaidah bahasa Qurani pemuda atau yang disebut "asy-syabab" didefinisikan dalam ungkapan sifat dan sikap seperti: 1). berani merombak dan bertindak revolusioner terhadap tatanan sistem yang rusak, seperti kisah pemuda (Nabi) Ibrahim. "Mereka berkata: 'Siapakah yang (berani) melakukan perbuatan ini terhadap tuhan-tuhan kami? Sesungguhnya dia termasuk orang orang yang zalim, Mereka berkata: Kami dengar ada seorang pemuda yang (berani) mencela berhala-berhala ini yang bernama Ibrahim."(QS.Al-Anbiya, 21:59-60). 2). memiliki standar moralitas (iman), berwawasan, bersatu, optimis dan teguh dalam pendirian serta konsisten dalam dengan perkataan, seperti tergambar pada kisah Ash-habul Kahfi (para pemuda penghuni gua). "Kami ceritakan kisah mereka kepadamu (Muhammad) dengan sebenarnya. Sesungguhnya mereka itu adalah pemuda.pemuda yang beriman kepada Tuhan mereka dan Kami tambahkan kepada mereka petunjuk; dan Kami telah meneguhkan hati mereka di waktu mereka berdiri, lalu mereka mengatakan: "Tuhan kami adalah Tuhan langit dan bumi; kami sekali-kali tidak menyeru Tuhan selain Dia, sesungguhnya kami kalau demikian telah mengucapkan perkataan yang amat jauh dari kebenaran"(QS.18: 13-14). 3). seorang yang tidak berputus-asa, pantang mundur sebelum cita-citanya tercapai. Seperti digambarkan pada pribadi pemuda (Nabi) Musa. "Dan (ingatlah) ketika Musa berkata kepada muridnya, "Aku tidak akan berhenti (berjalan) sebelum sampai kepertemuan dua buah lautan; atau aku akan berjalan sampai bertahun-tahun"(QS. AlKahfi,18: 60). 
Jadi pemuda identik dengan sebagai sosok individu yang berusia produktif dan mempunyai karakter khas yang spesifik, yaitu revolusioner, optimis, berpikiran maju, memiliki moralitas dan sebagainya. Kelemahan mencolok dari seorang pemuda adalah kontrol diri dalam artian mudah emosional, sedangkan kelebihan pemuda yang paling menonjol adalah mau menghadapi perubahan, baik berupa perubahan sosial maupun kultural dengan menjadi pelopor perubahan itu sendiri.

Peran penting dari seorang pemuda adalah pada kemampuannya melakukan perubahan. Perubahan menjadi indikator suatu keberhasilan terhadap sebuah gerakan pemuda. Perubahan menjadi sebuah kata yang memiliki daya magis yang sangat kuat, sehingga membuat gentar orang yang mendengarnya, terutama mereka yang telah merasakan kenikmatan dalam iklim status quo. Kekuatannya begitu besar, hingga dapat menggerakkan kinerja seseorang menjadi lebih produktif. Keinginan akan suatu perubahan melahir sosok pribadi yang berjiwa optimis. Optimis bahwa hari depan pasti lebih baik.

Remaja adalah masa kematangan atau kedewasaan. Masa ini merupakan masa yang paling rawan dalam kehidupan manusia. Anak muda mempunyai tingkat emosional yang sangat tinggi serta mudah terpengaruh oleh segala sesuatu yang didengar dan disaksikan. Oleh karena itu, krisis remaja pada saat ini lebih kompleks dan lebih rawan.

Harapannya adalah pada masa mendatang mereka akan menjadi tiang masyarakat dan memegang tanggung jawab di dalamnya. Remaja adalah pemindah warisan dan kejayaan dari generasi tua ke para remaja atau dari bapak ke cucu. Kalau suatu masyarakat merasa rugi karena generasi mudanya telah rusak, maka masyarakat itu telah kehilangan eksistensinya.

Lingkungan sosial remaja sangat mempengaruhi pembentukan jiwa, tujuan, prinsip, dan sebagainya. Apabila lingkungan telah mengajarkan mereka untuk berbuat menyimpang, maka perbuatan menyimpang tersebut akan menjadi 
suatu kebiasaan. Dan apabila lingkungan mengajarkan mereka untuk berbuat baik meraka tidak akan terbiasa dan tidak akan bisa untuk berbuat menyimpang, sehingga sangat kecil kemungkinan bagi mereka yang telah diajarkan oleh lingkungannya tentang menghadapi kerasnya hidup yang pernah masalah, dan menyelesaikannya untuk lari dari masalah mereka (frustasi) dan berakibat melakukan aktivitas yang terlarang, seperti mengkonsumsi minuman keras dan narkoba sebagai palariannya, karena mereka terlalu tegar untuk dirapuhkan. Krisis Iman dan Taqwa Kepada Tuhan Yang Maha Esa

Keimanan dan ketaqwaan seorang remaja sangat mempengaruhi jalan pikiran, tujuan prinsip dan perilaku mereka. Remaja yang selalu beribadah tetapi imtaqnya kurang maka remaja itu masih mudah rapuh. Berbeda dengan remaja yang beribadah dengan ikhlas dan memilih kualitas imtaq yang tinggi, dia akan memiliki pengendali diri (self controlling) yang kuat menahan dirinya untuk tidak terjerumus pada narkoba, karena dengan imtaqnya dia akan menjadi tegar dan berpondasi kuat.

Makin hari makin ramai dibicarakan orang gejala meningkatnya kenakalan atau kejahatan remaja. Sebagian cenderung mempersalahkan sekolah yang gagal menjalankan fungsinya, sebahagian lagi menyalahkan orangtua (terutama dari apa yang disebut golongan "elite"), sebagian lagi menyalahkan kebudayaan Barat. Ada pula yang menyalahkan pemuda itu sendiri. Bilamana dapat diketahui dengan lebih pasti jumlah dan jenis kenakalan atau kejahatan yang dilakukan oleh para remaja, kita akan lebih tertegun.

Kejahatan kanak-kanak adalah pengertian juridis, yang menetapkan batas umur tertentu dimana seorang remaja dihadapkan pada pengadilan kanakkanak bila ketahuan berbuat salah. Pengertian ini terbatas sekali sifatnya sebab tidaklah mempersoalkan kenakalan-kenakalan atau bentuk-bentuk protes yang dimanifestasikan oleh para pemuda dengan tidak usah merupakan sesuatu kejahatan (ditinjau dari ketertiban umum). Kenakalan pemuda sebagian besar adalah persoalan psychologis dan biososial. 
Secara populer terdapat pula pendapat bahwa para pemuda yang tergolong nakal pada umumnya adalah pemuda-pemuda yang bertingkat inteligensi rendah. Tetapi penyelidikan-penyelidikan tidak membuktikan kebenaran pendapat tersebut. Kejahatan kanak-kanak terdapat di kalangan pemuda yang berinteligensi agak rendah maupun di kalangan muda yang memiliki inteligensi cukup tinggi. Penyelidikan-penyelidikan tersebut selanjutnya tidak dapat membenarkan pendapat bahwa memang terdapat jenis kelompok manusia tertentu, yang mempunyai sifat-sifat kelompok jahat. Akan tetapi di dalam kenyataan sehari-hari memang dapat terjadi, bahwa kasus-kasus yang dihadapi oleh petugas-petugas hukum dan oleh para pendidik akan banyak terdiri dari mereka yang tidak tergolong cerdas.

Di dalam keadaan serupa ini, adalah tugas masyarakat untuk menyusun rencana-rencana kegiatan "lingkungan ketiga", (yaitu di dalam masyarakat sendiri, sesudah keluarga dan sekolah) yang bernilai edukatif dan rekreatif. Banyak kegiatan sosial yang dapat dilakukan oleh para pemuda, dan yang akan dilakukan oleh mereka dengan kegairahan, bilamana saja penyusunan program itu benar-benar berorientasi pada tahap-tahap perkembangan pemuda. Organisasi pencinta alam, organisasi kepanduan, kegiatan-kegiatan ilmiah reguregu kesejahteraan sosial, olahraga dan kesenian dan banyak lagi ternyata selalu menarik perhatian mereka untuk mereka jadikan bidang-bidang eksplorasi membentuk pribadi dan menemukan identitas mereka.

Organisasi kepemudaan sangat berperan penting dalam kehidupan bermasyarakat. Organisasi ini berfungsi untuk mengatur aspirasi pemuda dalam suatu kehidupan bermasyarakat, oleh karena itu jika dalam suatu daerah organisasi kepemudaannya berantakan, maka pemudanyapun bisa jadi akan hancur. Mungkin pemudanya akan mabuk-mabukkan dan sebagainya yang dapat menghancurkan hidupnya.

Seperti yang diuraikan di atas, hal itulah yang menjadi keresahan bersama, yang menjadi tantangan bersama terutama di Lingkungan Gegutu Timur 
Kelurahan Rembiga Kecamatan Selaparang, selama ini Pemuda di Lingkungan ini tidak atau kurang aktif dalam hal kegiatan-kegiatan kepemudaan, condong lebih mengarahkan diri kepada hal-hal yang sifatnya berhura-hura, mencari ketempat-tempat hiburan, berikutnya jalan-jalan yang tidak tahu arah atau tidak punya tujuan yang jelas, sehingga pada akhirnya akan berdampak pada masa depannya sendiri, lingkungan masyarakat berbangsa dan bernegara.

Kehawatiran berikutnya, akhir-akhir ini lagi populernya peristiwa Radikalisme yang berbuntut Terorisme, kebanyakan adalah pelakunya Remaja atau Pemuda yang mengatas namakan Agama, yaitu Jihad. Hal ini menjadi keprihatinan bersama semua pihak untuk lebih memberikan perhatian yang maksimal terhadap para Remaja atau Pemuda yang kedepannya menjadi pemimpin bangsa dan negara, khususnya di Lingkungan Gegutu Timur dengan kondisi riil di atas dapat dilihat nyata, kalau tidak sekarang kapan lagi kita berbuat. Tindaklanjut dari kegiatan ini adalah adanya perubahan mental dan spritual dari Pemudanya sendiri secara bertahap dan berkelanjutan diberikan perhatian, pemahaman dan motivasi untuk bisa lebih baik lagi dalam menata kehidupannya sendiri dan kehidupan bermasyarakat, intinya disini adalah Pemuda ini diberikan kesibukan tentunya yang positif mendukung kehidupan bermasyarakat tadi dengan cara melatih pemuda ini dalam kehidupan berorganisasi yang terkelola secara profesional dengan menggali potensi yang dimiliki oleh pemuda tersebut dalam wujud manajemen organisasi kepemudaan sebagai wadah untuk membina lebih intensif dalam hal pengelolaan potensi, minat bakat para pemuda, sehingga akan lebih terarah menata kehidupan yang lebih cerah kedepannya.

\section{PEMBAHASAN}

\section{Pemuda/Remaja Sebagai Aspek Kultural dan Indivudual.}

Konsepsi yang lebih bersifat politis di Indonesia pada umumnya menentukan batas umur pemuda (misalnya dalam organisasi gerakan pemuda) "antara 15 sampai 35 tahun hingga 40 tahun ". Akan tetapi konsepsi serupa ini tidak akan membawa kita lebih maju dalam usaha memahami pemuda dari sudut 
Bahrur Rosyid, Penguatan Konsep Parenting...

perkembangannya. Untuk periodisasi perkembangan itu secara psychologis pedagogis diperlukan pertimbangan-petimbangan yang lain.

Dalam membahas kedudukan pemuda/remaja di tengah-tengah masyarakat dalam era melenium seperti sekarang ini, pandangan resmi dari pandangan para ahli psikologi mengenai sifat golongan pemuda (15-35 tahun) itu antara lain adalah demikian: ".......manusia mengalami kejadian psychologis yang penting yakni pada masa transisi manusia meninggalkan masa ke kanakkanakan dan mempersiapkan diri untuk menjadi orang tua. Masa transisi ini terdiri atas beberapa periode; periode-periode yang terkenal seperti : periode Prae-oubertet, pubertet sebenarnya dan post-pubertet. "Sifatsifat permulaan dalam periode-periode tersebut diatas ialah munculnya keinginan menunjukkan sikap-sikap berani, ingin diperhatikan orang, yang sebenarnya sifatsifat tersebut pada permulaan hanya merupakan sifat yang demonstratif unuk menyembunyikan kegelisahan-kegelisahan yang belum dikenalnya.

Sikap-sikap ini dikemudian menjadi sempurna setelah ia dapat menemui dirinya sendiri, menemui harga kehidupan dan membuat percobaan dengan harga ini serta hasrat untuk segera masuk ke dalam masyarakat dan mengenal kebudayaan. Pada masa ini anak muda berusaha mendapatkan status sebagai manusia; ada kecenderungan untuk berusaha kearah emansipasi dengan melepaskan taraf ke kanak-kanakan di mana ia senantiasa harus tunduk kepada kehendak orang tua, karena dianggap rendah dalam umur, pengalaman dan kecakapan.

Perkembangan yang besar secara physis, intelektual dan emosional memberikan kepadanya dasar-dasar yang kuat untuk mendapatkan pengalaman dan pengetahuan dalam banyak lapangan, yang menjadi daya kritis dengan semakin banyak minat kepada soal-soal teoritis.Semakin berkembang pengertian serta penghargaan nilai-nilai semakin terbentuklah pandangan hidup serta cita-cita yang ingin dikejarnya dengan disertai kegiatan-kegiatan sosial, yang kini tidak lagi terbatas pada lingkungan rumah dan sekolah semata-mata. Dalam periode masa muda, sifat-sifat yang berani bertambah dengan sifat-sifat yang dinamis, revolusioner, radikal dan kritis. Sifat kepemudaan sudah lebih positif. 
Remaja adalah masa kematangan atau kedewasaan. Masa ini merupakan masa yang paling rawan dalam kehidupan manusia. Anak muda mempunyai tingkat emosional yang sangat tinggi serta mudah terpengaruh oleh segala sesuatu yang didengar dan disaksikan. Oleh karena itu, krisis remaja pada saat ini lebih kompleks dan lebih rawan. Harapannya adalah pada masa mendatang mereka akan menjadi tiang masyarakat dan memegang tanggung jawab di dalamnya. Remaja adalah pemindah warisan dan kejayaan dari generasi tua ke para remaja atau dari bapak ke cucu. Kalau suatu masyarakat merasa rugi karena generasi mudanya telah rusak, maka masyarakat itu telah kehilangan eksistensinya.

\section{Permasalah Pemuda/Remaja :}

\section{Krisis Sosial / Lingkungan}

Lingkungan sosial remaja sangat mempengaruhi pembentukan jiwa, tujuan, prinsip, dan sebagainya. Apabila lingkungan telah mengajarkan mereka untuk berbuat menyimpang, maka perbuatan menyimpang tersebut akan menjadi suatu kebiasaan. Dan apabila lingkungan mengajarkan mereka untuk berbuat baik meraka tidak akan terbiasa dan tidak akan bisa untuk berbuat menyimpang, sehingga sangat kecil kemungkinan bagi mereka yang telah diajarkan oleh lingkungannya tentang menghadapi kerasnya hidup yang pernah masalah, dan menyelesaikannya untuk lari dari masalah mereka (frustası) dan berakibat melakukan aktivitas yang terlarang, seperti mengkonsumsi minuman keras dan narkoba sebagai palariannya. Karena mereka terlalu tegar untuk dirapuhkan.

\section{Krisis Iman dan Taqwa Kepada Tuhan Yang Maha Esa}

Keimanan dan ketaqwaan seorang remaja sangat mempengaruhi jalan pikiran, tujuan prinsip dan perilaku mereka. Remaja yang selalu beribadah tetapi imtaqnya kurang maka remaja itu masih mudah rapuh. Berbeda dengan remaja yang beribadah dengan ikhlas dan memilih kualitas imtag yang tinggi, dia akan memiliki pengendali diri (self controlling) yang kuat menahan dirinya untuk tidak 
terjerumus pada narkoba, karena dengan imtaqnya dia akan menjadi tegar dan berpondasi kuat.

\section{Interaksi Sosial Menjelang Dewasa.}

Persoalan-persoalan yang penting dalam pertumbuhan seorang pemuda/remaja menjelang dewasa adalah:

1. Pemuda Secara Pribadi dan Masalah Penyesuaian.

Pembicaraan mengenai soal-soal penyesuaian. Agaknya antara lain hal ini disebabkan oleh kenyataan bahwa perubahan syarat-syarat hidup itu selalu meminta kemampuan dari setiap individu untuk menyesuaikan diri sehingga masalah penyesuaian diri menjadi satu masalah yang serius bagi manusia yang tengah berkembang itu.

Dengan bertambahnya pengalaman dan pengetahuan mereka, minat-minat tertentu dapat dikembangkan dan minat-minat yang lain dapat diadakan. Malahan dengan pengalaman dan pengetahuan baru itu, dapat ambil minat-minat yang baru pula. Nampaknya ada hubungan yang erat antara jenis-jenis minat dengan taraf kematangan seseorang. Pada masa awal, minat umumnya bersifat sangat pribadi dalam arti kata sangat berpusat pada Aku seorang remaja. Tetapi kemudian akan tampak bahwa dengan makin dewasa, minat akan berkembang ke arah sifat sosial. Hal ini nampak baik di dalam kalangan pemuda-pemuda Indonesia maupun di kalangan pemuda-pemuda di luar negeri yang memiliki sifat kebudayaan yang berlainan. Minat bergantung pada pengalaman, tetapi tidak ditentukan olehnya saja sebab sifat-sifat pribadi ikut pula menentukan perkembangannya. Malahan perkembangan fisik dan pengaruh-pengaruh kelenjar tubuhnyapun dapat mempengaruhi minat seseorang.

Kematangan jiwanya dari tahun ke tahun memperlihatkan perhatian yang mahir pada kaidah-kaidah sosial dan nilai-nilai kesusilaan yang terdapat dalam masyarakat orang dewasa. Sehingga makin mendekatkan mereka pada taraf kedewasaan makin kokoh dan stabil pula minat-minat mereka terhadap soal-soal tertentu. Umumnya, minat-minat mereka disesuaikan hampir-hampir "dengan sendirinya" dengan norma-norma sosial. Hanya di dalam situasi tertentu di mana 
seorang pemuda menghendaki sesuatu bentuk yang menyimpang dari norma sosial, barulah mulai timbul persoalan yang serius bagi pemuda/remaja itu sendiri. Keadaan serupa ini dapat menimbulkan situasi konflik yang sangat mempengaruhi sikap dan perbuatan mereka.

Sikap sebagai sebuah bentuk perkembangan, adalah penting sekali di dalam menentukan perbuatan seseorang, oleh karena unsur-unsur penting di dalam sikap mencakup sifat-sifat seperti taraf pengetahuan prasangka, pandanganpandangan terpola, kecenderungan-kecenderungan serta perasaan-perasaan tertentu mengenai setiap hal, baik di dalam arti yang positif maupun negatif.Prasangka-prasangka yang tertanam sedemikian awal itu nampak kemudian sangat besar pengaruhnya terhadap proses pembentukan Konsep-Aku pada pemuda/remaja.

Secara umum, aspek kepribadian di bidang sikap ini dapat dikatakan lebih bersifat idealistis daripada bersifat realistis. Hal ini menimbulkan kecenderungan mereka untuk - bila diperlukan - tidak mengikuti "cara" orang dewasa yang usang". Hanya di dalam hal-hal yang bersifat intelektuil nampak bahwa adolesen lebih mudah berpedoman pada pandangan-pandangan orang dewasa, dan bersedia untuk mengikuti sebanyak mungkin.

Sikap-sikap penyesuaian diri para pemuda selanjutnya berkaitan dengan :

a) Pemuda/remaja dengan Keluargal

b) Pemuda/remaja dengan sesame pemuda

c) Pemuda/remaja dengan masyarakat.

2. Pemuda/remaja di Persimpangan Jalan

Makin hari makin ramai dibicarakan orang gejala meningkatnya kenakalan atau kejahatan remaja. Sebagian cenderung mempersalahkan sekolah yang gagal menjalankan fungsinya, sebahagian lagi menyalahkan orangtua (terutama dari apa yang disebut golongan "elite'), sebagian lagi menyalahkan kebudayaan Barat. Ada pula yang menyalahkan pemuda itu sendiri. Bilamana dapat diketahui dengan lebih pasti jumlah dan jenis kenakalan atau kejahatan yang dilakukan oleh para remaja, kita akan lebih tertegun.

Kejahatan kanak-kanak adalah pengertian juridis, yang menetapkan batas umur tertentu dimana seorang remaja dihadapkan pada pengadilan kanak-kanak 
bila ketahuan berbuat salah. Pengertian ini terbatas sekali sifatnya sebab tidaklah mempersoalkan kenakalan-kenakalan atau bentuk-bentuk protes yang dimanifestasikan oleh para pemuda dengan tidak usah merupakan sesuatu kejahatan (ditinjau dari ketertiban umum). Kenakalan pemuda sebagian besar adalah persoalan psychologis dan biososial.

Secara populer terdapat pula pendapat bahwa para pemuda yang tergolong nakal pada umumnya adalah pemuda-pemuda yang bertingkat inteligensi rendah. Tetapi penyelidikan-penyelidikan tidak membuktikan kebenaran pendapat tersebut. Kejahatan kanak-kanak terdapat di kalangan pemuda yang berinteligensi agak rendah maupun di kalangan muda yang memiliki inteligensi cukup tinggi. Penyelidikan-penyelidikan tersebut selanjutnya tidak dapat membenarkan pendapat bahwa memang terdapat jenis kelompok manusia tertentu yang mempunyai sifat-sifat kelompok jahat. Akan tetapi di dalam kenyataan sehari-hari memang dapat terjadi, bahwa kasus-kasus yang dihadapi oleh petugas-petugas hukum dan oleh para pendidik akan banyak terdiri dari mereka yang tidak tergolong cerdas.

Di dalam keadaan serupa ini, adalah tugas masyarakat untuk menyusun rencana-rencana kegiatan "lingkungan ketiga" (yaitu di dalam masyarakat sendiri, sesudah keluarga dan sekolah) yang bernilai edukatif dan rekreatif. Banyak kegiatan sosial yang dapat dilakukan oleh para pemuda dan yang akan dilakukan oleh mere-ka dengan kegairahan, bilamana saja penyusunan program itu benarbenar berorientasi pada tahap-tahap perkembangan pemuda.

Organisasi pencinta alam, organisasi kepanduan, kegiatan-kegiatan ilmiah regu-regu kesejahteraan sosial, olahraga dan kesenian, dan banyak lagi ternyata selalu menarik perhatian mereka untuk mereka jadikan bidang-bidang eksplorasi membentuk pribadi dan menemukan identitas mereka.

Buku pengantar manajemen karya Dr. H.B. Siswanto, M.Si yang terdiri dari 10 bab ini ditulis berdasarkan atas keprihatinan sang penulis terhadap fenomena yang terjadi di masyarakat yang menganggap bahwa manajemen merupakan suatu konsep yang sangat sederhana yang sering dirangkaikan pada permasalahan tertentu. Buku ini menekankan dua hal yang mendasar yakni 
manajemen sebagai suatu ilmu dan seni, sebagai suatu ilmu, manajemen merupakan akumulasi pengetahuan yang telah disitematisasikan menjadi satu kesatuan yang terpadu sehingga menjadi pegangan dasar dalam melakukan tindakan ilmiah sedangkan manajemen sebagai suatu seni merupakan suatu keahlian, kemampuan, kemahiran, serta keterampilan dalam aplikasi prinsip, metode, dan teknik dalam menggunakan sumber daya manusia dan sumber daya lainnya secara efisien dan efektif.

\section{Pelaksanaan Kegiatan}

Kegiatan ini dilakukan oleh Pengabdi/TIM dengan teknis Pelatihan Manajemen Organisasi Kepemudaan dalam Upaya Penguatan Idealisme Kepemudaan Guna Menangkal Paham Radikalisme di Lingkungan Gegutu Timur, Rembiga, Selaparang, Kota Mataram dengan melibatkan Pemuda atau Remaja Masjid Lingkungan Gegutu Timur, sebagai peserta pelatihan. Metode Pelatihan ini dilakukan diawali dengan menggunakan Partisipatory action research, yaitu dengan tim fasilitator (dosen) beserta trainnernya (Tokoh Pemuda, sekaligus tokoh masyarakat), mencoba untuk berdialog dengan Kepala Lingkungan Gegutu Timur dan Ketua Remaja Masjid. Dialog ini dilakukan secara intensif guna menggali lebih jauh masalah-masalah yang menjadi hambatan Remaja Masjid. Serta menggali informasi kaitannya dengan kondisi informasi kaitannya dengan Tingkat Pendidikan Para Pemuda, Tingkat Perekonomian Keluarganya, kondisikondisi seperti inilah faktor pedukung besar yang mengakibat pemuda terjerumus kedalam kenakalan remaja. Dari hasil PAR ini diharapkan menjadi bahan rujukan dalam pembuatan Model Pelatihannya, Pembinaan dengan Kegiatan ini dimaksudkan untuk memberikan orientasi dengan tujuan memberikan wawasan, pengetahuan dan pembinaan melalui pola Pendekatan dengan sistem PAR bagi Pembinaan Manajemen Organisasi Kepemudaan dalam Upaya Penguatan Idealisme Kepemudaan Guna Menangkal Paham Radikalisme di Lingkungan Gegutu Timur, Rembiga, Selaparang, Kota Mataram, sehingga akan terjadi keseimbangan dalam menjalankan kehidupan antara Pemuda yang memiliki tingkat pendidikan tinggi dengan pendidikan rendah, antara masyarakat yang 
lemah secara ekonomi dengan masyarakat yang kuat ekonominya, sehingga satu sama lain saling membutuhkan, hal ini bisa tercapai dengan kami memberikan pengetahuan tentang bagaimana cara atau prosedur merangkul Pemuda sebagai motor penggerak dalam kemajuan masyarakat, khususnya di Lingkungan Gegutu Timur, Diagram Venn; digunakan untuk melihat hubungan individu dengan Lingkungan yang ada dalam suatu Wadah, yaitu organisasi kepemudaan atau Remaja Masjid. Dengan teknik ini, fasilitator dan trainner mengajak Warga Lingkungan Gegutu Timur khususnya yang dilatih adalah Pemuda atau Remaja Masjid, secara bersama-sama untuk mengidentifikasi Potensi yang ada di Internal dan Eksternal Pemuda atau Remaja Masjid, menganalisis dan mengkaji peran dan kepentingannya dalam Wadah Organisasi Kepemudaan atau Remaja Masjid serta mempertanyakan manfaat eksistensi Wadah tersebut bagi masyarakat khususnya dan Lingkungan Gegutu Timur Umumnya. Wawancara Semi Terstruktur adalah penggalian informasi berupa tanya jawab yang sistematis tentang pokok-pokok tertentu. Wawancara ini bersifat terbuka dan santai, namun dibatasi oleh topik/masalah yang telah dipersiapakan. Focused Group Discussion (FGD), yaitu aktivitas diskusi kelompok yang terfokus untuk mengidentifikasi potensi, peluang, tantangan dan masalah yang ada dalam menjalankan Wadah organisasi kepemudaan atau remaja masjid yang bersangkutan, proses diskusi disini mencakup :

a) Praktek operasionalnya kegiatan Remaja Masjid, bagaimana proses memulai menjalankan kegiatannya khususnya kegiatan dalam meramaikan masjid, bagaimana menjalan sistem di dalam organisasinya sendiri, bagaimana proses pengembangannya, dari sisi sumberdaya manusia, berikut mentrainningnya, sehingga kedepannya mampu menjalan operasional organisasi secara keseluruhan.

b) Monitoring dan Evaluasi dalam menjalankan operasional Organisasi Remaja Masjid, yang tidak kalah serunya lagi, yaitu bagaimana teknis memonitoring operasional Remaja Masjid, mengendalikan perjalanan kegiatannya, sehingga taraf terakhirnya mengadakan evaluasi dari hasil monitoring tersebut. 
Transformasi, Vol. 13, No. 2, Juli 2017:147 - 163

c) Pembuatan Laporan kegiatan kepada kepala lingkungan, bagaiamana menyusun laporan kegiatan, ini dilakukan sekilas saja, berikut kalau ada waktu lagi di tahun depannya lagi diadakan secara khusus untuk dilatih bagaimana proses menyusun laporan kegiatan.

Agar kegiatan ini berhasil, maka TIM juga akan melakukan evaluasi. Evaluasi dalam kegiatan Pelatihan Manajemen Organisasi Kepemudaan dalam Upaya Penguatan Idealisme Kepemudaan Guna Menangkal Paham Radikalisme di Lingkungan Gegutu Timur, Rembiga, Selaparang, Kota Mataram, ini dilakukan setelah pelaksanaan kegiatan dilakukan. Materi evaluasi terkait dengan pelaksanaan kegiatan mengikuti siklus sebagaimana tahapan Identifikasi, Perencanaan Pelaksanaan, Evaluasi, Identifikasi. ${ }^{5}$

Tahap awal evaluasi adalah dengan melakukan identifikasi, terjadi perubahan pengetahuan, sikap dan budaya (kompetisi dan memiliki daya saing tinggi) dari Pelatihan Manajemen Organisasi Kepemudaan dalam Upaya Penguatan Idealisme Kepemudaan Guna Menangkal Paham Radikalisme di Lingkungan Gegutu Timur, Rembiga, Selaparang, Kota Mataram dapat menjadi penguatan sisi ekonomi, sebagai momentum peningkatan perekonomian masyarakat di Lingkungan Gegutu Timur, Rembiga, Selaparang, Kota Mataram, dapat Mengembangkan Pendidikan dan ekonomi Remaja Masjid Lingkungan Gegutu Timur, Rembiga, Selaparang, Kota Mataram.

Peluang, kelemahan dan kekuatan yang ada dalam program yang direncanakan. Setelah identifikasi, menyusun kembali program agar dapat diaplikasikan sesuai dengan periode yang telah ditentukan. Selanjutnya adalah pelaksanan program yang telah dievaluasi. Dalam proses evaluasi ini akan selalu melibatkan stake holder.

\footnotetext{
${ }^{5}$ Maimun, dkk., Panduan Kuliah Kerja Nyata, (Mataram : LPM IAIN Mataram, 2007), h. 23.
} 


\section{PENUTUP}

Dari hasil PAR ini diharapkan menjadi bahan rujukan dalam pembuatan Model Pelatihannya, Pembinaan dengan Kegiatan ini dimaksudkan untuk memberikan orientasi dengan tujuan memberikan wawasan, pengetahuan dan pembinaan melalui pola Pendekatan dengan sistem PAR bagi Pembinaan Manajemen Organisasi Kepemudaan dalam Upaya Penguatan Idealisme Kepemudaan Guna Menangkal Paham Radikalisme di Lingkungan Gegutu Timur, Rembiga, Selaparang, Kota Mataram, sehingga akan terjadi keseimbangan dalam menjalankan kehidupan antara Pemuda yang memiliki tingkat pendidikan tinggi dengan pendidikan rendah, antara masyarakat yang lemah secara ekonomi dengan masyarakat yang kuat ekonominya, sehingga satu sama lain saling membutuhkan, hal ini bisa tercapai dengan kami memberikan pengetahuan tentang bagaimana cara atau prosedur merangkul Pemuda sebagai motor penggerak dalam kemajuan masyarakat, khususnya di Lingkungan Gegutu Timur, Diagram Venn; digunakan untuk melihat hubungan individu dengan Lingkungan yang ada dalam suatu Wadah, yaitu organisasi kepemudaan atau Remaja Masjid. Dengan teknik ini, fasilitator dan trainner mengajak Warga Lingkungan Gegutu Timur khususnya yang dilatih adalah Pemuda atau Remaja Masjid, secara bersama-sama untuk mengidentifikasi Potensi yang ada di Internal dan Eksternal Pemuda atau Remaja Masjid, menganalisis dan mengkaji peran dan kepentingannya dalam Wadah Organisasi Kepemudaan atau Remaja Masjid serta mempertanyakan manfaat eksistensi Wadah tersebut bagi masyarakat khususnya dan Lingkungan Gegutu Timur Umumnya. Wawancara Semi Terstruktur adalah penggalian informasi berupa tanya jawab yang sistematis tentang pokok-pokok tertentu. Wawancara ini bersifat terbuka dan santai, namun dibatasi oleh topik/masalah yang telah dipersiapakan. Focused Group Discussion (FGD), yaitu aktivitas diskusi kelompok yang terfokus untuk mengidentifikasi potensi, peluang, tantangan dan masalah yang ada dalam menjalankan Wadah organisasi kepemudaan atau remaja masjid yang bersangkutan, proses diskusi disini mencakup: Praktek operasionalnya kegiatan Remaja Masjid, bagaimana proses memulai menjalankan kegiatannya khususnya kegiatan dalam meramaikan masjid, bagaimana menjalan sistem di dalam organisasinya sendiri, bagaimana proses 
pengembangannya, dari sisi sumberdaya manusia, berikut mentrainningnya, sehingga kedepannya mampu menjalan operasional organisasi secara keseluruhan, Monitoring dan Evaluasi dalam menjalankan operasional Organisasi Remaja Masjid, yang tidak kalah serunya lagi, yaitu bagaimana teknis memonitoring operasional Remaja Masjid, mengendalikan perjalanan kegiatannya, sehingga taraf terakhirnya mengadakan evaluasi dari hasil monitoring tersebut., Pembuatan Laporan kegiatan kepada kepala lingkungan, bagaiamana menyusun laporan kegiatan, ini dilakukan sekilas saja, berikut kalau ada waktu lagi di tahun depannya lagi diadakan secara khusus untuk dilatih bagaimana proses menyusun laporan kegiatan.

Agar kegiatan ini berhasil, maka TIM juga akan melakukan evaluasi. Evaluasi dalam kegiatan Pelatihan Manajemen Organisasi Kepemudaan dalam Upaya Penguatan Idealisme Kepemudaan Guna Menangkal Paham Radikalisme di Lingkungan Gegutu Timur, Rembiga, Selaparang, Kota Mataram, ini dilakukan setelah pelaksanaan kegiatan dilakukan. Materi evaluasi terkait dengan pelaksanaan kegiatan mengikuti siklus sebagaimana skema di bawah $\mathrm{ini}^{6}$ :

Identifikasi Perencanaan Pelaksanaan Evaluasi Identifikasi.

Tahap awal evaluasi adalah dengan melakukan identifikasi, terjadi perubahan pengetahuan, sikap dan budaya (kompetisi dan memiliki daya saing tinggi) dari Pelatihan Manajemen Organisasi Kepemudaan dalam Upaya Penguatan Idealisme Kepemudaan Guna Menangkal Paham Radikalisme di Lingkungan Gegutu Timur, Rembiga, Selaparang, Kota Mataram dapat menjadi penguatan sisi ekonomi, sebagai momentum peningkatan perekonomian masyarakat di Lingkungan Gegutu Timur, Rembiga, Selaparang, Kota Mataram, dapat Mengembangkan Pendidikan dan ekonomi Remaja Masjid Lingkungan Gegutu Timur, Rembiga, Selaparang, Kota Mataram.

\footnotetext{
${ }^{6}$ Maimun, dkk., Panduan Kuliah Kerja Nyata, (Mataram : LPM IAIN Mataram, 2007).
} 
Bahrur Rosyid, Penguatan Konsep Parenting...

\section{DAFTAR PUSTAKA}

Robbin, S.P. and Coulter, M., Management, Upper Saddle River, Eight Editions, New Jersey, Prentice Hall, 2005.

Hani Handoko, T.H., Manajemen, Edisi 2, BPFE UGM, Yogyakarta, 2000.

Manullang M., Dasar-dasar Manajemen. Gadjah Mada University. Yogyakarta, 2001.

Siagian, Manajemen Suatu Pengantar, Bandung: Alumni, 1997.

Oey Liang Lee, Pengertian Manajemen, Yogyakarta : Balai Pembinaan Administras, Universitas Gadjah Mada.

Pariata Westra, Pokok-pokok Pengertian IImu Manajemen, Yogyakarta : BPA Akademi Administrasi Negara, 1980.

Harold Koontz dan Crill O'Donnel, Principles of Management to Analysis Managerial Fungctions, Tokyo : Kogakusha Company, Ltd

William Herbert Newman, Administrative Action, New Jersey Prentice Hall Inc, Englewood Cliffs, 1957.

Louis A. Allen, Karya Manajemen, Jakarta : PT. Pembangunan, 1963.

Ernie Trisnawati Sule \& Kurniawan Saefullah,. Pengantar Manajemen, Prenada Media. Jakarta, 2004. 